\title{
The use of electronic tongue (e-tongue) as a simple and rapid method for honey authentication
}

\author{
1,2, ${ }^{*}$ Lestari, L.A., ${ }^{2,3}$ Triyana, K., ${ }^{1}$ Hanifah, A.K. and ${ }^{4}$ Wildiana, R.A. \\ ${ }^{1}$ Department of Nutrition and Health, Faculty of Medicine, Public Health and Nursing, Universitas Gadjah \\ Mada, Jalan Farmako, Sekip Utara, Yogyakarta 55281, Indonesia \\ ${ }^{2}$ Institute for Halal Industry and System, Universitas Gadjah Mada, Gedung LPPT, Jalan Kaliurang Km. 4, \\ Yogyakarta 55281, Indonesia \\ ${ }^{3}$ Department of Physics, Faculty of Mathematics and Natural Sciences, Universitas Gadjah Mada, Sekip \\ Utara Yogyakarta 55281, Indonesia \\ ${ }^{4}$ Department of Biostatistics, Epidemiology, and Population Health, Faculty of Medicine, Public Health, \\ and Nursing, Universitas Gadjah Mada, Yogyakarta 55281, Indonesia
}

\begin{abstract}
Article history:
Received: 30 October 2020

Received in revised form: 7

December 2020

Accepted: 16 February 2021

Available Online: 6 June

2021
\end{abstract}

Keywords:

Authentication,

Honey,

Electronic tongue,

Biosensor,

Rapid detection

DOI:

https://doi.org/10.26656/fr.2017.5(3).615

\begin{abstract}
A simple and rapid test for honey authentication is required particularly for the food industry to assure the quality of honey. The conventional methods for honey authentication are costly, requires a long waiting time to obtain results, requires highly skilled personnel, and is difficult in terms of sample preparation. The electronic tongue can be utilized as an alternative technique for honey authentication. The electronic tongue frameworks are depended on an array of sensors with low selectivity while being sensitive to several components in the measured sample. The signals gathered by the sensors are processed through pattern recognition tools to produce prediction models that permit the grouping of the samples and the measurement of a portion of their physicochemical properties. Papers that were published from 2015 to 2020 from several databases such as Google Scholar, ScienceDirect, and Pubmed were collected to obtain abstracts and original articles related to the authentication of honey-based on sugar content as well as geographical and botanical origin. This review highlighted the electronic tongue as a simple and rapid test for honey authentication, several original papers also compare the validity of electronic tongue with the high-performance liquid chromatography methods as the gold standard.
\end{abstract}

\section{Introduction}

Demands for honey is currently experiencing an increase due to the Covid-19 pandemic. In addition to vitamin, herbs, and micronutrients, honey could be used as an immune booster to prevent the SAR-CoV2 infection. The increasing demand for honey has sharpened the gap between supply and demand. Before the pandemic, according to the Ministry of Forestry, the Republic of Indonesia, the need for honey in Indonesia reached 7,000-15,000 tons per year, while the production was only 4,000 - 5,000 tons per year (IPB University, 2019). On the other hand, air pollution, new fastspreading fungal diseases and parasites, and the loss of habitat for flower caused a decrease in global honeybee populations. As a result, there are many honey adulterations conducted to overcome the gap between supply and demand. Honey can be adulterated in two ways, namely direct and indirect adulteration. In terms of direct adulteration, the direct addition of certain substances such as glucose, fructose, or sucrose to the honey is carried out. Meanwhile, indirect adulteration occurs when honeybees are fed with adulterating substances (Zábrodská and Vorlová, 2014). According to the standards of Codex Alimentarius (FAO, 2001), "honey is a natural sweet substance produced by honeybees from the nectar of plants or from secretions of living parts of plants or excretions of plant-sucking insects on the living parts of plants, which the bees collect, transform by combining with specific substances of their own, deposit, dehydrate, store and leave in the honeycomb to ripen and mature". This definition suggests that the addition of substances to the honey is not allowed, even in small quantities.

The authenticity of honey can usually be seen from 
its production as well as its geographical and botanical origin. In terms of production, honey adulteration can be carried out by adding other food components, whereas based on the geographical regions or botanical origin, certain types of honey have a higher economic value. Hence, it is important to assess honey authenticity. There are many kinds of methods used to authenticate honey. The detection of honey adulteration can be done with traditional technologies such as NMR spectroscopy (He et al., 2020; Song et al., 2020), HPLC (Stanek et al., 2019; Aykas et al., 2020; Guzelmeric et al., 2020), stable carbon isotopic ratio mass spectrometry (SCIRA) (Geanâ et al., 2020), as well as the reflectance-Fourier transforms infrared spectroscopy (Riswahyuli et al., 2020). However, these techniques are expensive requires an extended amount of time to obtain results, requires highly skilled personnel, and is difficult in sample preparation (Sobrino-Gregorio et al., 2017). Therefore, simple and rapid technologies are needed to authenticate honey.

The electronic tongue frameworks are constructed on an array of sensors with low selectivity while being sensitive to several components in the measured sample. The signals gathered by the sensors are processed through pattern recognition tools to produce prediction models that permit the grouping of the samples and the measurement of a portion of their physicochemical properties (Sobrino-Gregorio et al., 2018). This review will outline the research published in the last five years on honey authentication utilizing an electronic tongue. Firstly, a brief explanation of the electronic tongue's principle of analysis was explored. Secondly, the authentication of honey according to the simples sugar content using an electronic tongue was discussed as simples sugar such as cane sugar, corn sugar, and cassava sugar are widely used to adulterate honey in Indonesia. Several methods such as HPLC, NMR spectroscopy, and SCIRA were compared with the electronic tongue for the validation of the electronic tongue. Finally, as the monofloral honey from a certain origin has a higher economic value, the use of the electronic tongue to differentiate honey based on geographical and botanical origin was explored to evaluate the honey adulteration.

\section{Methodology}

Original papers, abstracts, and reports related to the authentication of honey were collected from several databases such as Google Scholar, ScienceDirect, and Pubmed. The keywords used during the search for information were authentication, honey, and electronic tongue. Papers included were published from 2015 until
2020 to perform this review. A total of 347 research articles were found in the Google Scholar database, 73 research articles in the ScienceDirect database, and 4 articles in the Pubmed database. The articles were selected according to the relevance with the aim of this review.

\section{Electronic tongue}

Electronic tongue or e-tongue is an electrochemicalbased sensing tool, which is a technique for analysing food quality (Veloso et al., 2018). E-tongue is a qualitative analysis technique that allows classification and identification of samples, by working depending on the composition of the sensor array and mathematical procedures as well as multivariate data processing techniques (Sobrino-Gregorio et al., 2018).

The e-tongue system is based on a series of sensors with low selectivity but which are sensitive to several components in the sample namely cross-sensitivity. The signal will be collected through sensors and processed by identifying patterns to produce a predictive model that allows classification of the sample and calculating the number of certain physicochemical components in it. The resulting data is then processed using multivariate analysis techniques such as PCA (principal component analysis), LDA (linear discriminant analysis), or CA (cluster analysis). PCA is most often used to distinguish between samples (for example, between pure honey and refined sugar syrup), to calculate the amount of additional components in honey that has been adulterated, and to distinguish the level of addition of other components in honey (Sobrino-Gregorio et al., 2018).

The e-tongue can be used to evaluate food quality in the form of liquids, such as milk, tea, honey, and others. The e-tongue is able to detect markers of honey adulteration and can distinguish between pure honey and honey adulterated with sugar syrup, as well as estimating the level of adulteration. In recent decades, e-tongue has been reported to be able to classify honey according to its geographical origins and detect the presence of unnatural chemical components in honey. According to Zábrodská and Vorlová (2014), e-tongue is able to independently distinguish honey from monofloral or polyfloral nectar, honey made from sugar syrup, and a mixture of honey with sugar syrup. The use of e-tongue for honey evaluation can be potentiometric or voltammetric based. Voltammetry bases are the most widely used with high sensitivity, flexibility and simplicity. This voltammetric test-based e-tongue works through 4 electrodes ( $\mathrm{Ir}, \mathrm{Rh}, \mathrm{Pt}, \mathrm{Au}$ ) in a stainless-steel cylinder which is used as part of the e-tongue tools 
(Sobrino-Gregorio et al., 2018).

According to Veloso et al. (2018), the e-tongue electrochemical device is known as an innovative detection technology, works fast, is flexible, sensitive, accurate, has easy procedures, and does not require specific operators. However, like all other method devices, the e-tongue also has its disadvantages, namely that the e-tongue sensor needs to be conditioned and calibrated using an acid or electrolyte solution when it is used. This method also requires some special cleaning procedures, namely when the measurement is taking place or after the test is complete, this is done to clean the remaining sample from the sensor surface, ensuring the resulting signal remains stable and can be used again. This sensor cleaning system requires special care and expense (Sobrino-Gregorio et al., 2018).

\section{Honey authentication using electronic tongue based on the simple sugar content}

According to Se et al. (2019), various biochemical parameters can be measured to detect honey adulteration, including sucrose content, fructose-glucose-sucrose profile, oligosaccharide content, proline content, and hydroxymethylfurfural (HMF) levels. HMF is a good indicator for detecting adulterated honey because it can indicate the presence of inverted sugar. According to Suhartini et al. (2018), HMF is a compound resulting from the decomposition of fructose that should not be present in pure honey, so that it can be a sign of inadequate storage, excessive heating, or adulteration with added sugar. In pure honey, most of the carbohydrates contained are from the monosaccharide type glucose and fructose, and there is only a small amount of the type of oligosaccharide. According to The Codex Alimentarius and Indonesian National Standards (SNI number 01-3545-2013), the sugar content of honey is listed in Table 1.

According to Damto (2019), no oligosaccharides with a degree of polymerization of more than 5 are found in honey, but these oligosaccharides are abundant in starch syrup, so the high content of oligosaccharides is also an indicator of adulteration of honey with starch syrup. In addition, diastase enzyme activity also has an important role in detecting concentrations and classifying types of additives in honey. The amount and activity of the diastase enzyme decreased in the adulteration of honey with sucrose syrup and HFCS (Suhartini et al., 2018; Damto, 2019). Chemical composition analysis is usually used to detect direct adulteration, but this method is relatively time-consuming, requires sample preparation and equipment, as well complex analysis (Zábrodská and Vorlová, 2014). Carbohydrate composition, mainly the concentrations of fructose and glucose, as well as their ratio, have been useful indicators for the classification of unifloral kinds of honey as independent parameters or combined with other physicochemical parameters, such as electrical conductivity (Karabagias, 2019).

Table 1. Sugar and other chemical composition of honey-based on Indonesia National Standards (SNI 01-3545-2013)

\begin{tabular}{|c|c|c|}
\hline Type of Sugar & SNI & Codex \\
\hline Glucose and Fructose $^{1}$ & $\operatorname{Min} 65 \%$ & Min $60 \%$ \\
\hline Sucrose $^{2}$ & $\operatorname{Max} 5 \%$ & $\operatorname{Max} 5 \%$ \\
\hline Hydroxymethyfurfural (HMF) ${ }^{3}$ & Max $50 \mathrm{mg} / \mathrm{kg}$ & Max 40 or $80 \mathrm{mg} / \mathrm{kg}$ \\
\hline Diastase enzyme activity ${ }^{4}$ & Min 3 Shade Units & Min 3 Shade Units \\
\hline Water content & $\operatorname{Max} 22 \%$ & $\operatorname{Max} 20 \%$ \\
\hline Free acidity & Max $50 \mathrm{ml} \mathrm{NaOH} / \mathrm{kg}$ & Max 50 milliequivalents acid per $1000 \mathrm{~g}$ \\
\hline Water Insoluble Solids Content & Max $0.5 \%$ & Max $0.1 \%$ or $0.5 \%$ for pressed honey \\
\hline Ash & Max $0.5 \%$ & \\
\hline \multicolumn{3}{|l|}{ Heavy metal } \\
\hline Lead & Max $2.0 \mathrm{mg} / \mathrm{kg}$ & \multirow{5}{*}{$\begin{array}{l}\text { Absent or not to exceed maximum levels } \\
\text { allowed }\end{array}$} \\
\hline Cadmium & Max $0.2 \mathrm{mg} / \mathrm{kg}$ & \\
\hline Mercury & Max $0.03 \mathrm{mg} / \mathrm{kg}$ & \\
\hline Arsenic & Max $1.0 \mathrm{mg} / \mathrm{kg}$ & \\
\hline Chloramphenicol & Not detected & \\
\hline
\end{tabular}

${ }^{1}$ The content of glucose and fructose according to the Codex Alimentarius is the sum of glucose and fructose, while according to SNI, it was calculated based on the reducing sugar content

${ }^{2}$ Several kinds of honey such as Alfalfa (Medicago sativa), Citrus spp., False Acacia (Robinia pseudoacacia), French Honeysuckle (Hedysarum), Menzies Banksia (Banksia menziesii), Red Gum (Eucalyptus camaldulensis), Leatherwood (Eucryphia lucida), Eucryphia milligani could contain sucrose maximum at 10\%, while Lavender (Lavandula spp) and Borage (Borago officinalis) could contain sucrose maximum at $15 \%$

${ }^{3}$ The HMF content shall not be more than $40 \mathrm{mg} / \mathrm{kg}$, with an exception of honey from countries or region with tropical ambient temperatures which allowed HMF content maximum at $80 \mathrm{mg} / \mathrm{kg}$

${ }^{4}$ In general not less than 8 Schade units and in the case of honey with a low natural enzyme content not less than 3 Schade Units. 
For many years, sugar-based syrups are chosen to adulterate honey. There are 2 types of honey adulteration with sugar, namely direct and indirect adulteration. Direct adulteration is directly added honey with syrups, whereas indirect adulteration is feeding the honeybees with sugars to obtain more honey during the harvest time. This kind of adulteration is difficult to detect since sugar syrups have a similar chemical composition to honey. The honey adulterants include fructose syrup, sugar cane, sucrose, date syrup, invert sugar, rice syrup, maltose syrup, as well as corn syrup (Aliaño-González et al., 2019; Se et al., 2019). Hence, it is important to discriminate pure honey from adulterated honey. Adulteration of honey with sugar addition can be detected using a method of AOAC 977.20 for sugar profile and a method of AOAC 991.41 internal standard for SCIRA (stable carbon isotope ratio analysis). As it is mentioned before, these methods cannot be used as a rapid and easy method for honey authentication. Hence, the development of e-tongue for honey authentication is needed.

Several studies had already used e-tongue for honey authentication based on sugar profiles (Table 2). The chemometric-integrated voltammetric e-tongue could detect adulteration with sugar syrups as low as $2.5 \%$ (Sobrino-Gregorio et al., 2018).

The possibility of assessing honey authenticity through the identification of sugar syrup adulterants had been evaluated by using physicochemical methods in addition to a rapid and effective voltammetric e-tongue method, thus, achieving incorrect classification methodologies (Oroian et al., 2018). A pulse voltammetry electronic tongue system (with $\mathrm{Ir}, \mathrm{Rh}, \mathrm{Pt}$, and $\mathrm{Au}$ working electrodes), including PCA analysis, was capable of discriminating between different types of pure honey, syrups, and different levels of adulterants incorporated in honey. PLS models were proposed so as to predict the addition of syrups in honey, hence the addition of syrups can be estimated quantitatively (Sobrino-Gregorio et al., 2018). An electronic tongue (based on seven potentiometric chemical sensors and an $\mathrm{Ag} / \mathrm{AgCl}$ standard electrode), as well as PCA analysis, was more suitable for honey authentication compared to spectral data (NIR, MIR) (Gan et al., 2016).

\section{Honey authentication using electronic tongue based on geographical and botanical origin}

Honey may be a complicated product, with its composition varying depending on the kind of flower, bee species, geographic region, season, and storage conditions (Jovetić et al., 2017). Kinds of honey with identical floral origin may have different chemical compositions due to different weather conditions and soil characteristics. Investigations of floral and geographical origins are important issues for the authentication process. Selection of suitable instrumental techniques and specific markers able to resolve these issues may be a challenge (Zábrodská and Vorlová, 2014).

Table 2. Summary of several studies regarding honey authenticity using e-tongue to detect sugar syrups as adulterants (research articles between 2017-2020)

\begin{tabular}{|c|c|c|c|c|}
\hline Purpose & E-tongue Condition & Country & Remarks & References \\
\hline $\begin{array}{l}\text { To discriminate } \\
\text { Hungarian honey based } \\
\text { on physicochemical } \\
\text { properties }\end{array}$ & $\begin{array}{l}\alpha \text { Astree electronic tongue } \\
(\mathrm{ET}) \text { consist of a sensor } \\
\text { array with seven } \\
\text { potentiometric sensors } \\
\text { developed for food } \\
\text { applications and an } \mathrm{Ag} / \\
\text { AgCl reference electrode. }\end{array}$ & Hungary & $\begin{array}{l}\text { Results showed that the merged data } \\
\text { of electronic tongue and electrical } \\
\text { conductivity provided the best } \\
\text { models for the prediction of the main } \\
\text { physicochemical properties of honey. }\end{array}$ & $\begin{array}{l}\text { Koncz, Bodor, } \\
\text { Kaszab et al. } \\
(2017) ; \\
\text { Koncz, Bodor, } \\
\text { Rashed et al. } \\
(2017)\end{array}$ \\
\hline $\begin{array}{l}\text { To detect adulteration of } \\
\text { honey with Barley, corn, } \\
\text { and brown rice syrups } \\
(2,5 \%, 5 \%, 10 \%, 20 \% \text {, } \\
\text { and } 40 \%)\end{array}$ & $\begin{array}{l}\text { Pulse Voltammetric } \\
\text { electronic tongue/PCA, } \\
\text { PLS }\end{array}$ & Spain & $\begin{array}{l}\text { PCA analysis revealed that the e- } \\
\text { tongue is able to discriminate } \\
\text { between pure honey, syrups, and } \\
\text { different levels of adulterants. }\end{array}$ & $\begin{array}{l}\text { Sobrino- } \\
\text { Gregorio et al. } \\
(2018)\end{array}$ \\
\hline $\begin{array}{l}\text { To evaluate the } \\
\text { physicochemical } \\
\text { properties of linden and } \\
\text { acacia honey (authentic } \\
\text { and adulterated ones } \\
\text { with sugar syrup) using } \\
\text { standard methods as well } \\
\text { as electronic sensory } \\
\text { technique namely e- } \\
\text { tongue and e-nose }\end{array}$ & $\begin{array}{l}\text { A commercial e-tongue } \\
\text { was performed by } \alpha \text { Astree } \\
\text { electronic tongue. } \\
\text { The commercial NST3320 } \\
\text { type electronic nose was } \\
\text { used as well. }\end{array}$ & Hunga & $\begin{array}{l}\text { E-tongue could recognize and predict } \\
\text { between adulterated and authentic } \\
\text { honey }>90 \% \text { compare to the standard } \\
\text { method, whereas e-nose has the } \\
\text { ability }>80 \% \text {. } \\
\text { Adulteration with } 10 \% \text { of sugar is } \\
\text { more difficult to detect compared to } \\
20 \% \text { and } 50 \% \text { sugar syrup addition. }\end{array}$ & $\begin{array}{l}\text { Bodor et al. } \\
(2020)\end{array}$ \\
\hline
\end{tabular}

PCA: principal component analysis, PLS: partial least square 
The e-tongue and e-nose analyses supported by chemometrics are widely utilized with good success for differentiating kinds of honey collected from different botanical and geographical origins (Huang et al., 2015; Bougrini et al., 2016). Different types of classification models were constructed and compared based on the fingerprints of e-tongue sensors, NIR as well as MIR spectra of pure and adulterated honey (Gan et al., 2016). Gan et al. (2016) assessed four PCA models based on the characteristics of e-tongue, likewise NIR and MIR spectra to group the pure honey and adulterated honey with rice syrup (RS) and corn syrup (COSS) as much as $5,10,20$, and $40 \%$.

In general, the authentication of the botanical origin of honey involves the identification and quantification of honey specific compounds and properties, followed by comparison with naturally present values. The classical approaches used for the authentication of monofloral honey are supported by honey's physicochemical, melissopalynological, and sensory analysis. The rapid techniques for the honey classification and prediction based on botanical and geographical origin can be done with potentiometric and voltammetric electronic tongues (Bougrini et al., 2016). Pattern recognition techniques (PCA, DFA, PCR, PLSR, and LS-SVM) applied to the electronic tongue's signals give very stable performances in predicting the botanical origin of honey with different geographical origins (Wei and Wang, 2014). Although the electronic nose and the electronic tongue devices ensure good discrimination of honey, depending on botanical origin, however, spectroscopic techniques, e.g., NIR and MIR, are preferred, because of their higher

Table 3. Authentication of honey using e-tongue based on botanical and geographical origin (research articles between 20172020)

\begin{tabular}{|c|c|c|c|c|}
\hline Purpose & E-tongue Condition & Country & Remarks & References \\
\hline $\begin{array}{l}\text { To detect the authenticity } \\
\text { of } 55 \text { honey samples and } \\
\text { adulterated honey } \\
\text { samples with fructose, } \\
\text { malt wort, IS and HIS }\end{array}$ & $\begin{array}{l}\text { Voltammetric e-tongue } \\
\text { with PLS-LDA, MLR }\end{array}$ & Romania & $\begin{array}{l}\text { Using e-tongue data, } 83.33 \% \text { LDA } \\
\text { correct classification of authentic and } \\
\text { adulterated honey was achieved. }\end{array}$ & $\begin{array}{l}\text { Oroian et al. } \\
(2018)\end{array}$ \\
\hline $\begin{array}{l}\text { To authenticate } 5 \text { types } \\
\text { of honey using a } \\
\text { voltammetric tongue }\end{array}$ & $\begin{array}{l}\text { VE tongue using } 6 \\
\text { electrodes (silver, gold, } \\
\text { platinum, glass, zinc oxide } \\
\text { and titanium dioxide). The } \\
\text { data was analyzed using } \\
\text { PCA and LDA }\end{array}$ & Romania & $\begin{array}{l}\text { The electrodes of titanium dioxide, } \\
\text { zinc oxide, and silver were more } \\
\text { useful than the others since they give } \\
\text { a better classification of honey } \\
\text { according to the botanical origin. }\end{array}$ & $\begin{array}{l}\text { Pauliuc et al. } \\
(2020)\end{array}$ \\
\hline $\begin{array}{l}\text { To compare e-tongue } \\
\text { with } \\
\text { melissopalynological } \\
\text { analysis in pollen } \\
\text { profiles analysis }\end{array}$ & $\begin{array}{l}\text { A commercial } \\
\text { potentiometric E-tongue } \\
\text { ( } \alpha \text { Astree, Alpha M.O.S., } \\
\text { Toulouse, France) with } \\
\text { seven potentiometric } \\
\text { sensors }\end{array}$ & Italy & $\begin{array}{l}100 \% \text { results matched between } \\
\text { melissopalynological analysis with } \\
\text { the potentiometric electronic tongue }\end{array}$ & $\begin{array}{l}\text { Di Rosa et al. } \\
(2018)\end{array}$ \\
\hline $\begin{array}{l}\text { To evaluate the } \\
\text { alectrochemical data } \\
\text { from } 5 \text { different honey } \\
\text { (acacia, sunflower, tilia, } \\
\text { honeydew, and } \\
\text { polyfloral) }\end{array}$ & $\begin{array}{l}\text { Voltammetric electronic } \\
\text { tongue with } \mathrm{Ag} / \mathrm{AgCl} \\
\text { reference electrode, glassy } \\
\text { counter electrode, and } \mathrm{Au} \text {, } \\
\mathrm{Ag}, \mathrm{Pt} \text {, or glassy working } \\
\text { electrode. } \\
\text { The electrochemical data } \\
\text { were analyzed with } \\
\text { principal component } \\
\text { analysis (PCA) and linear } \\
\text { discriminant analysis } \\
\text { (LDA). }\end{array}$ & Romania & $\begin{array}{l}\text { The silver and gold electrodes could } \\
\text { classify honey much better than glass } \\
\text { or platinum electrode. }\end{array}$ & $\begin{array}{l}\text { Oroian and } \\
\text { Ropciuc (2019) }\end{array}$ \\
\hline $\begin{array}{l}\text { To discriminate honey of } \\
\text { botanical origin }\end{array}$ & $\begin{array}{l}\text { e-tongue with } 4 \text { conducting } \\
\text { materials namely thermal } \\
\text { evaporated thin film of } \\
\text { gold on a glass slide, a } \\
\text { carbon film, a glass slide } \\
\text { coated with an Indium-Tin- } \\
\text { Oxide (ITO) layer, and a } \\
\text { highly doped n-type silicon }\end{array}$ & Morocco & $\begin{array}{l}\text { The e-tongue can distinguish honey } \\
\text { with almost identical sugar and } \\
\text { moisture contents. The gold electrode } \\
\text { has much better result compare to } \\
\text { others. }\end{array}$ & $\begin{array}{l}\text { Elamine et al. } \\
(2019)\end{array}$ \\
\hline
\end{tabular}

PCA: principal component analysis, PLS: partial least square, LDA: linear discriminant analysis 
accuracy. Additionally, methods of sample preparation and pre-treatment are needed in the sensory analysis (e.g., equilibration of honey aroma within the case of electronic nose and sample dilution within the case of the electronic tongue), thus affecting the applicability for real-time and on-site measurement (Gan et al., 2016).

Several studies pertaining to discrimination of honey -based on botanical and geographical origin have been done internationally in some countries in Europe such as Romania (Oroian, Amariei, Rosu, et al., 2015; Oroian, Prisacaru, Hretcanu et al., 2015; Oroian and Ropciuc, 2018; Oroian et al., 2018; Oroian and Ropciuc, 2019; Pauliuc et al., 2020), Greece (Karabagias et al., 2017; Karabagias, Nikolaou and Gatzias, 2017), Italy (Bontempo et al., 2017; Di Rosa, Leone, Scattareggia et al., 2018; Di Rosa, Leone, Cheli et al., 2018; Di Rosa, Marino, Leone et al., 2018), Morocco (Elamine et al., 2019), as well as other countries such as Africa (Adgaba et al., 2017) and Australia (Sniderman et al., 2018). However, only several studies are using the electronic tongue to discriminate kinds of honey (Table 3).

One of the naturally present substances in honey that can be used to discriminate honey is pollen. Pollen analysis is effective for discriminate honey produced in different areas. However, it has limitations since it is laborious and time-consuming (Sniderman et al., 2018). Physicochemical parameters namely $\mathrm{pH}$, electrical conductivity, moisture, ash content, total acidity, viscosity, colour, as well as sugar composition can be applied as good discrimination of honey-based on their geographical origin. This is indicating that the physicochemical parameters of honey represent important tracers for honey geographical origin determination (Adgaba et al., 2017).

\section{Conclusion}

The e-tongue is a highly convenient tool for carrying out an authenticity test on honey. Therefore, it is a promising tool in the future to ensure the quality of honey. However, several efforts are needed to assemble the basic characteristics of the various honey and sugarbased adulterants in relation to the developed e-tongue, as well as the need for a more versatile sensor that can accurately examine the authenticity of honey. By combining the chemometrics data analysis with the etongue output characteristics, on-site accurate and largescale screening of quality of honey samples becomes possible, as these biosensors are capable to detect adulterations in honey to as low as $2.5 \%$.

\section{Conflict of interest}

Authors declare no conflict of interest.

\section{Acknowledgments}

The publication of this paper was supported by Directorate of Research, Universitas Gadjah Mada (UGM) through the Rekognisi Tugas Akhir (RTA) grant number 2488/UN1.P.III/DIT-LIT/PT/2020 granted to Dr Lily Arsanti Lestari.

\section{References}

Adgaba, N., Al-Ghamdi, A.A., Getachew, A., Tadesse, Y., Belay, A., Ansari, M.J. and Sharma, D. (2017). Characterization of honeys by their botanical and geographical origins based on physico-chemical properties and chemo-metrics analysis. Journal of Food Measurement and Characterization, 11(3), 1106-1117. https://doi.org/10.1007/ s11694-0179487-4.

Aliaño-González, M.J., Ferreiro-González, M., EspadaBellido, E., Palma, M. and Barbero, G.F. (2019). A screening method based on Visible-NIR spectroscopy for the identification and quantification of different adulterants in high-quality honey. Talanta, 203, 235-241. https://doi.org/10.1016/ j.talanta.2019.05.067

Aykas, D.P., Shotts, M.-L. and Rodriguez-Saona, L.E. (2020). Authentication of commercial honeys based on Raman fingerprinting and pattern recognition analysis. Food Control, 117, 107346. https:// doi.org/10.1016/j.foodcont.2020.107346

Bodor, Z., Benedek, C., Kaszab, T., Zinia Zaukuu, J.-L., Kertesz, I. and Kovacs, Z. (2019). Classical and Correlative Analytical Methods for Origin Identification of Hungarian Honeys. Acta Alimentaria, 48(4), 477-487. https:// doi.org/10.1556/066.2019.48.4.9

Bontempo, L., Camin, F., Ziller, L., Perini, M., Nicolini, G. and Larcher, R. (2017). Isotopic and elemental composition of selected types of Italian honey. Measurement, 98, 283-289. https://doi.org/10.1016/ j.measurement.2015.11.022

Bougrini, M., Tahri, K., Saidi, T., El Hassani, N.E., Bouchikhi, B. and El Bari, N. (2016). Classification of Honey According to Geographical and Botanical Origins and Detection of Its Adulteration Using Voltammetric Electronic Tongue. Food Analytical Methods, 9, 2161-2173. https://doi.org/10.1007/ s12161-015-0393-2

Damto, T. (2019). A Review on Effect of Adulteration on Honey Properties. SSRN Electronic Journal, 3359494. https://doi.org/10.2139/ssrn.3359494

Di Rosa, A.R., Leone, F., Scattareggia, C. and Chiofalo, V. (2018). Botanical origin identification of Sicilian honeys based on artificial senses and multi-sensor 
data fusion. European Food Research Technology, 244, 117-125. https://doi.org/10.1007/s00217-0172945-8

Di Rosa, A.R., Leone, F., Cheli, F. and Chiofalo, V. (2018). Novel approach for the characterisation of Sicilian honeys based on the correlation of physicochemical parameters and artificial senses. Italian Journal of Animal Science, 18(1), 389-397. https://doi.org/10.1080/1828051X.2018.1530962

Di Rosa, A.R., Marino, A.M.F., Leone, F., Corpina, G.G., Giunta, R.P. and Chiofalo, V. (2018). Characterization of Sicilian Honeys Pollen Profiles Using a Commercial E-Tongue and Melissopalynological Analysis for Rapid Screening: A Pilot Study. Sensors, 18(11), 4065. https:// doi.org/10.3390/s18114065

Elamine, Y., Inácio, P.M.C., Lyoussi, B., Anjos, O., Estevinho, L.M., Miguel, M.D. and Gomes, H.L. (2019). Insight into the sensing mechanism of an impedance based electronic tongue for honey botanic origin discrimination. Sensors and Actuators B: Chemical, 285, 24-33. https://doi.org/10.1016/ j.snb.2019.01.023

FAO. (2001). Food and Agriculture Organization of the United Nations. Revised codex standard for honey (No. CODEX STAN 12-1981). Retrieved August 29, 2020 from FAO website: www.fao.org/input/ download/standards/310/cxs_012e.pdf

Gan, Z., Yang, Y., Li, J., Wen, X., Zhu, M., Jiang, Y. and Ni, Y. (2016). Using sensor and spectral analysis to classify botanical origin and determine adulteration of raw honey. Journal of Food Engineering, 178, 151-158. https://doi.org/10.1016/ j.jfoodeng.2016.01.016

Geanâ, E.-I., Ciucure, C.T., Costinel, D. and Ionete, R.E. (2020). Evaluation of honey in terms of quality and authenticity based on the general physicochemical pattern, major sugar composition and $\partial^{13}$ C. Food Control, 109, 106919. https://doi.org/10.1016/ j.foodcont.2019.106919

Guzelmeric, E., Ciftci, I., Yuksel, P.I. and Yesilada, E. (2020). Importance of chromatographic and spectrophotometric methods in determining authenticity, classification and bioactivity of honey. Lebensmittel-Wissenschaft and Technologie, 132, 109921. https://doi.org/10.1016/j.lwt.2020.109921

He, C., Liu, Y., Liu, H., Zheng, X., Shen, G. and Feng, J. (2020). Compositional identification and authentication of Chinese honeys by $1 \mathrm{H} \mathrm{T}$ NMR combined with multivariate analysis. Food Research International, 130, 108936. https://doi.org/10.1016/ j.foodres.2019.108936
Huang, L., Liu, H., Zhang, B. and Wu, D. (2015). Application of electronic nose with multi-variate analysis and sensor selection for botanical origin identification and quality determination of honey. Food and Bioprocess Technology, 8, 359-370. https://doi.org/10.1007/s1 1947-014-1407-6

IPB University. (2019). Prospek Agribisnis Lebah Madu. Retrieved September 2, 2020 from website: http:// fapet.ipb.ac.id/index.php/direktori/2016-06-08-01-43 -33/berita/1045-prospek-agribisnis-lebah-madu

Jovetić, M., Trifković, J., Stanković, D., Manojlović, D. and Milojković-Opsenica, D. (2017). Mineral Content as a Tool for the Assessment of Honey Authenticity. Journal of AOAC International, 100 (4), 862-870. https://doi.org/10.5740/jaoacint.170145. https://doi.org/10.5740/jaoacint.17-0145

Karabagias, I.K. (2019). Seeking of reliable markers related to Greek nectar honey geographical and botanical origin identification based on sugar profile by HPLC-RI and electrochemical parameters using multivariate statistics. European Food Research and Technology, 245(4), 805-816. https:// doi.org/10.1007/s00217-018-3216-z

Karabagias, I.K., Louppis, A.P., Karabournioti, S., Kontakos, S., Papastephanou, C. and Kontominas, M.G. (2017). Characterization and geographical discrimination of commercial Citrus spp. honeys produced in different Mediterranean countries based on minerals, volatile compounds and physicochemical parameters, using chemometrics. Food Chemistry, 217, 445-455. https:// doi.org/10.1016/j.foodchem.2016.08.124

Karabagias, I.K., Nikolaou, C. and Gatzias, I. (2017). The impact of geographical origin on specific properties of pine honey. Annals of Advances in Chemistry, 1, 23-31. https://doi.org/10.29328/ journal.aac. 1001003

Koncz, F.A., Bodor, Z., Kaszab, T., Kertesz, I., Zaukuu, J.L.Z., Benedek, C., Gillay, Z. and Kovacs, Z. (2017). Prediction of main analytical and Physical parameters of honey with electronic tongue. Hungarian Agricultural Engineering, 32, 38-43. https://doi.org/10.17676/HAE.2017.32.38

Koncz, F.A., Bodor, Z., Rashed, M.S., Kaszab, T., Gillay, B., Kovacs, Z. and Benedek, C. (2017). Floral and geographical origin identification of Hungarian honey with electronic tongue and classical analytical methods. Analecta, 11(2), 1-9. https://doi.org/10.14232/analecta.2017.2.1-9

Oroian, M. and Ropciuc, S. (2018). Botanical authentication of honeys based on Raman spectra. Journal of Food Measurement and Characterization, 12, 545-554. https:// doi.org/10.1007/s11694-017- 
9666-3.

Oroian, M. and Ropciuc, S. (2019). Romanian honey authentication using voltammetric electronic tongue. Correlation of voltammetric data with physicochemical parameters and phenolic compounds. Computers and Electronics in Agriculture, 157, 371379. https://doi.org/10.1016/j.compag.2019.01.008

Oroian, M., Amariei, S., Rosu, A. and Gutt, G. (2015). Classification of unifloral honeys using multivariate analysis. Journal of Essential Oil Research, 27(6), 533-544. doi.org/10.1080/10412905.2015.1073183

Oroian, M., Paduret, S. and Ropciuc, S. (2018). Honey adulteration detection: Voltammetric e-tongue versus official methods for physicochemical parameter determination. Journal of the Science and Food Agriculture, 98(11), 4304-4311. https:// doi.org/10.1002/jsfa.8956

Oroian, M., Prisacaru, A., Hretcanu, E.C., Stroe, S.-G. and Buculei, A. (2015). Heavy Metals Profile in Honey as a Potential Indicator of Botanical and Geographical Origin. International Journal of Food Properties, 19(8), 1825-1836. https:// doi.org/10.1080/10942912.2015.1107578

Pauliuc, D., Dranca, F. and Oroian, M. (2020). Raspberry, Rape, Thyme, Sunflower and Mint Honeys Authentication Using Voltammetric Tongue. Sensors, 20(9), 2565. https://doi.org/10.3390/ s20092565

Riswahyuli, Y., Rohman, A., Setyabudi, F.M.C.S. and Raharjo, S. (2020). Indonesian wild honey authenticity analysis using attenuated total reflectance-fourier transform infrared (ATR-FTIR) spectroscopy combined with multivariate statistical techniques. Heliyon, 6, e03662. https:// doi.org/10.1016/j.heliyon.2020.e03662

Se, K.W., Wahab, R.A., Yaacob, S.N.S. and Ghoshal, S.K. (2019). Detection techniques for adulterants in honey: Challenges and recent trends. Journal of Food Composition and Analysis, 80, 16-32. https:// doi.org/10.1016/j.jfca.2019.04.001

Sniderman, J.M.K., Matley, K.A., Haberle, S.G. and Cantrill, D.J. (2018). Pollen analysis of Australian honey. PloS One, 13(5), e0197545. https:// doi.org/10.1371/journal. pone.0197545.

Sobrino-Gregorio, L., Bataller, R., Soto, J. and Escriche, I. (2018). Monitoring honey adulteration with sugar syrups using an automatic pulse voltammetric electronic tongue. Food Control, 91, 254-260. https://doi.org/10.1016/j.foodcont.2018.04.003

Sobrino-Gregorio, L., Vargas, M., Chiralt, A. and Escriche, I. (2017). Thermal properties of honey as affected by the addition of sugar syrup. Journal of Food Engineering, 213, 69-75. https:// doi.org/10.1016/j.jfoodeng.2017.02.014

Song, X., She, S., Xin, M., Chen, L, Li, Y., Heyden, Y.V., Rogers, K.M. and Chen, L. (2020). Detection of adulteration in Chinese monofloral honey using ${ }^{1} \mathrm{H}$ nuclear magnetic resonance and chemometrics. Journal of Food Composition and Analysis, 86, 103390. https://doi.org/10.1016/j.jfca.2019.103390

Stanek, N., Teper, D., Kafarski, P. and Jasicka-Misiak, I. (2019). Authentication of phacelia honey (Phacelia tanacetifolia) based on a combination of HPLC and HPTLC analyses as well as spectrophotometric measurements. Lebensmittel-Wissenschaft and Technologie, 107, 199-207. https://doi.org/10.1016/ j.lwt.2019.03.009

Suhartini, E.A., Moechtar, J. and Darmawati, A. (2018). Mutu Produk Madu yang Dijual di Surabaya. Jurnal Farmasi dan Ilmu Kefarmasian Indonesia, 5(1), 4555. https://doi.org/10.20473/jfiki.v5i12018.45-55

Veloso, A.C.A., Sousa, M.E.B.C., Estevinho, L., Dias, L.G. and Peres, A.M. (2018). Honey Evaluation Using Electronic Tongues: An Overview. Chemosensors, 6(3), 28. https://doi.org/10.3390/ chemosensors 6030028

Wei, Z. and Wang, J. (2014). Tracing floral and geographical origins of honeys by potentiometric and voltammetric electronic tongue. Computers and Electronics in Agriculture, 108, 112-122. https:// doi.org/10.1016/j.compag.2014.07.014

Zábrodská, B. and Vorlová, L. (2014). Adulteration of honey and available methods for detection - a review. Acta Veterinaria Brno, 83(10), S85-S102. https://doi.org/10.2754/avb201483S10S85 